\title{
Pengembangan Pompa Irigasi Pertanian Menggunakan Energi Listrik Tenaga Surya di Desa Duri, Slahung, Ponorogo
}

\section{(Development of Agricultural Irrigation Pump Using Solar Electric Energy in Duri Village, Slahung, Ponorogo)}

\author{
Didik Riyanto ${ }^{1}$, Yoyok Winardi' ${ }^{2}$, Mohammad Muhsin ${ }^{1}$ \\ 1 Program Studi Teknik Elektro, Fakultas Teknik, Universitas Muhammadiyah Ponorogo, Jl. Budi Utomo No.10, \\ Ronowijayan, Siman, Kabupaten Ponorogo, Jawa Timur 63471. \\ 2 Program Studi Teknik Mesin, Fakultas Teknik, Universitas Muhammadiyah Ponorogo, Jl. Budi Utomo No.10, Ronowijayan, \\ Siman, Kabupaten Ponorogo, Jawa Timur 63471. \\ *Penulis Korespondensi: ndoroboys@gmail.com \\ Diterima Agustus 2020/Disetujui Mei 2021
}

\begin{abstract}
ABSTRAK
Program pengabdian kepada masyarakat mengembangkan irigasi pertanian dilaksanakan di Desa Duri, Kecamatan Slahung, Kabupaten Ponorogo. Pertanian di Desa Duri selama ini tergantung pada pengairan dari hujan, sehingga aktivitas pertanian hanya mengandalkan ketersediaan air saat musim hujan, sementara potensi air dari air tanah dengan kedalaman $20 \mathrm{~m}$ belum mampu dimanfaatkan secara maksimal karena terkendala peralatan dan teknologi yang relatif mahal. Program pengabdian kepada masyarakat ini bertujuan untuk memenuhi kebutuhan pengairan bagi petani. Metode pelaksanaaan kegiatan terdiri dari inventarisasi data terkait kondisi dan kebutuhan bahan yang akan diterapkan dengan teknologi, perancangan teknologi, penerapan teknologi, pelatihan penggunaan teknologi, dan evaluasi. Hasil kegiatan merupakan program penerapan pompa irigasi dengan listrik tenaga surya yang diterapkan pada salah satu ladang kelompok tani, yaitu pompa air yang mampu mengangkat air dari kedalaman 20 m dengan keluaran debit air 1080 L/jam dan mampu bertahan selama 2 jam. Hasil dari program yang dilaksanakan mampu memenuhi kebutuhan air di musim kemarau dan dapat digunakan untuk bercocok tanam pada skala kecil seperti tanaman sayuran pada luas lahan $100 \mathrm{~m}$.
\end{abstract}

Kata kunci: irigasi, listrik, pertanian, surya, tenaga

\begin{abstract}
Community service program To develop agricultural irrigation is carried out in Duri village, Slahung subdistrict, Ponorogo district. Agriculture in Duri village has been dependent on irrigation from the rain so agricultural activities only rely on the availability of water during the rainy season, while the potential for water from groundwater with a depth of $20 \mathrm{~m}$ has not been able to be utilized optimally because it is constrained by relatively expensive equipment and technology. For this reason, a community service program is carried out which aims to meet the irrigation needs of farmers. The method of implementing activities consists of an inventory of data related to the conditions and needs of materials to be applied with technology, technology design, technology application, training in the use of technology, and evaluation. The result of the activity is a program of implementing an irrigation pump with solar cell electricity that is applied to one of the farmer groups' fields, namely a water pump that is able to lift water from a depth of $20 \mathrm{~m}$ with a water discharge of 1080 $\mathrm{L} /$ hour and is able to last for 2 hours. able to meet water needs in the dry season and can be used to grow crops on a small scale such as vegetable crops on a land area of $100 \mathrm{~m}$.
\end{abstract}

Keywords: agriculture, electricity, irrigation, power, solar

\section{PENDAHULUAN}

Desa Duri merupakan salah satu desa yang sebagian besar penduduknya bermata pencaharian sebagai petani. Pertanian di Desa Duri mengandalkan sistem pengairan tadah hujan karena Desa Duri tidak dilewati aliran sungai dari waduk atau bendungan, sehingga sistem bercocok tanam di Desa Duri umumnya hanya dilakukan di saat musim hujan meskipun ada beberapa wilayah yang saat musim kemarau masih bisa bercocok tanam dengan memanfaatkan air tanah yang dipompa menggunakan mesin (Harini 2019).

Penggunan mesin pompa pada sistem pertanian di Desa Duri hanya dilakukan oleh sebagian kecil petani, karena sumber air tanah saat musim kemarau mencapai kedalaman 20 m 
dari permukaan tanah, sehingga dibutuhkan sebuah pompa khusus yang mampu mengangkat air karena pompa air dengan tenaga mesin diesel umumnya hanya mampu mengangkat air dengan kedalaman maksimum $10 \mathrm{~m}$ dari permukaan tanah, sehingga sebagian besar petani tidak menggarap sawah atau ladang mereka disaat musim kemarau karena tidak adanya air untuk pengairan lahan sawah dan ladang sehingga mengakibatkan kapasitas produksi pertanian tidak banya (BAPPEDA Kabupaten Ponorogo, 2018).

Permasalahan yang dihadapi petani dalam upaya peningkatan produksi pertanian adalah sarana irigasi yang mampu mencukupi kebutuhan air untuk bercocok tanam bagi para petani. Solusi yang ditawarkan pada mitra untuk membantu menyelesaikan permasalahan yang ada saat ini berupa program penerapan teknologi pompa air yang mampu mengangkat air tanah untuk pengairan Pertanian (Fitri 2017). Maka, kegiatan pengabdian ini bertujuan untuk membantu memenuhi kebutuhan air pada sistem pertanian di Desa Duri dengan menerapakan teknologi moderen dan ramah lingkungan melalui pengembangan pompa air berenergi listrik tenaga surya untuk irigasi.

Indikator keberhasilan program ini dilihat dari aspek kemanfaatan teknologi tepat guna yang diberikan dan peningkatan produksi pertanian. Permasalahan terhadap kebutuhan pengairan petani teratasi dengan adanya teknologi ini (Arifin et al. 2020). Teknologi pompa air berenergi listrik tenaga surya diharapkan juga dapat mengenalkan energy terbaru kepada petani sehingga dapat memberikan wawasan bahwa prtani mampu menghasilkan energy listrik secara mandiri dan lebih ramah lingkungan (Sanjaya et al. 2019).

\section{METODE PELAKSANAAN}

\section{Lokasi dan Partisipan Kegiatan}

Kegiatan pengabdian masyarakat dilaksanakan di desa Duri, Kecamatan Slahung, Kabupaten Ponorogo. Mitra yang terlibat dalam kegiatan adalah anggota kelompok Tani Doro Manunggal, pemilik lahan pertanian lahan kering atau lahan tadah hujan. Lahan ini memiliki potensi sumber air tanah dan dengan partisipan siap menyediakan sumur bor yang akan di pasang teknologi pompa pengairan dengan tenaga listrik tenaga surya serta bersedia menjaga dan memanfaatkan dengan baik.

\section{Bahan dan Alat}

Bahan dan alat yang digunakan dalam kegiatan ini adalah peralatan irigasi pertanian pompa listrik bertenaga surya yang digunakan untuk mengairi tanaman sayuran di lahan kering, terdiri dari seperangkat sistem pembangkit listrik tenaga surya sistem portable dengan daya $840 \mathrm{WH}$ terdiri dari panel surya $200 \mathrm{WP}$, solar control charger 10A, batterey-penyimpanan accu $12 \mathrm{~V} 70 \mathrm{Ah}$ lead acid batterey, inverter 2000 watt sine pure wave, pompa submer sible $0,5 \mathrm{Hp}$, dan peralatan sistem pengairan tanaman (Sanjaya 2019).

\section{Metode Pelaksanaan Kegiatan}

Kegiatan penerapan teknologi pompa air berenergi listrik tenaga surya pada petani sayur di Desa Duri dimulai dengan inventarisasi data di lapangan terkait permasalahan yang dihadapi oleh petani melalui metode penggalian data studi lapangan dan wawancara dengan mitra, selanjutnya tim melakukan analisis dan desain teknologi guna memberikan solusi yang dihadapi oleh mitra, desain teknologi dilanjutkan dengan perancangan alat di laboratorium Fakultas Teknik, Universitas Muhammadiyah Ponorogo, setelah perancangan selesai selanjutnya dilakukan uji kelayakan pakai, kemudian dilakukan perakitan dan penerapan pada lokasi kebun sayur milik mitra kegiatan, selanjutnya dilakukan pelatihan penggunakan alat terhadap mitra sebagai pengguna teknologi ini, evaluasi dan pendampingan untuk mengetahui seberapa besar pemanfaatan teknologi yang diterapkan (Yasar et al. 2017).

Keberhasilan program dinilai dari seberapa besar pemanfaatan teknologi untuk keberlangsungan budi daya pertanian di Desa Duri khususnya pada pertanian tanaman sayur di lahan kering atau tadah hujan dalam upaya memenuhi kebutuhan. Keberhasilan program juga dilihat dari seberapa alat dapat menghasilkan air untuk mengairi tanaman sayur, dinama tanaman sayur membutuhkan pengairan dua kali sehari sebesesar $130 \mathrm{~mm} /$ hari dengan harapan pompa dapat mengalirkan debit air sebesar $1000 \mathrm{~L} / \mathrm{jam}$.

\section{HASIL DAN PEMBAHASAN}

\section{Pelaksanaa kegiatan}

Kegiatan pengabdian masyarakat dimulai dengan melakukan penggalian data di lapangan terkait permasalahan yang dihadapi petani di 
Desa Duri Kecamatan Slahung Kabupaten Ponorogo. Berdasarkan analisis situasi, dapat diuraikan permasalahan mitra sebagai berikut: 1) Irigasi tergantung pada musim hujan sehingga pada musim kemarau terjadi kelangkaan air untuk pengairan sawah, untuk menanam sayur dibutuhkan minimal 1,1 mm/hari setiap tanama; 2) Desa Duri tidak dilewati sungai besar yang mencukupi untuk pengairan, sehingga mengandalkan pompa air bertenaga diesel yang memerlukan bahan bakar bensin atau solar yang menimbulkan asap (pencemaran udara) dan biaya mahal; 3) Petani sayur membutuhkan teknologi system pengairan yang ramah lingkungan agar hasil sayur tidak terkena polusi bahan kimia; 4) Dibutuhkan sebuah upaya untuk menekan biaya pengairan yang murah dalam bercocok tanam khususnya pada musim kemarau; dan 5) Petani Desa Duri pada saat musim kemarau tidak dapat menanam tanaman karena kurangya air untuk kebutuhan pengairan sehingga petani perlu membuat inovasi dalam bercocok tanam.

Desain Teknologi atau alat dilakukan oleh tim program di laboratorium Fakultas Teknik, Universitas Muhammadiyah, dimulai dengan perencanaan dan perancangan pompa irigasi pertanian bertenaga panel surya. Perencanaan alat mendasar pada penggalian data dilapangan terkait kondisi dan kebutuhan mitra serta melakukan kajian dari beberapa sumber pustaka (Dewi et al. 2017). Adapun kegiatan perencanaan dan perancangan pompa irigasi pertanian bertenaga panel surya dijelaskan sebagai berikut:

\section{- Kegiatan perencanaan teknologi}

Perencanaan teknologi dilakukan bersama tim program pengabdian kepada masyarakat di laboratorium meliputi peralatan yang akan diterapkan di ladang dan persawahan mitra, dari hasil data yang diperoleh saat melakukan studi lapangan. Hasil diskusi tim menetapkan bahwa peralatan yang dikembangkan meliputi pompa air listrik tenaga surya dengan spesifikasi pompa air celup submersible 0,5 HP daya dorong $30 \mathrm{~m}$, daya listrik 370 watt. Pembangkit listrik tenaga surya dengan model portable dengan daya 800 watt/jam dan kemampuan panel surya mengubah energi matahari menjadi listrik $200 \mathrm{WP}$ (Kadir 2010) kegiatan perencanaan teknologi disajikan pada Gambar 1 dan gambaran umum alat yang akan di rancang disajikan pada Gambar 2 .

\section{- Kegiatan perancangan teknologi}

Kegiatan perancangan alat dilakukan di bengkel laboratorium Teknik Mesin oleh anggota tim program pengabdian, alat terdiri dari dua bagian, yakni bagian kerangka alat dengan spesifikasi bagian rangka alat yang dijelaskan pada Tabel 1, dan bagian komponen alat dengan spesifikasi yang dijelaskan pada Tabel 2.

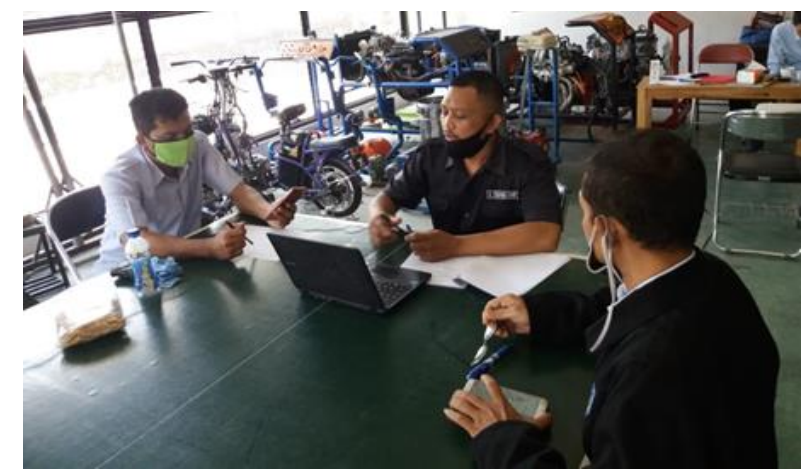

Gambar 1 Diskusi perencanaan teknologi.

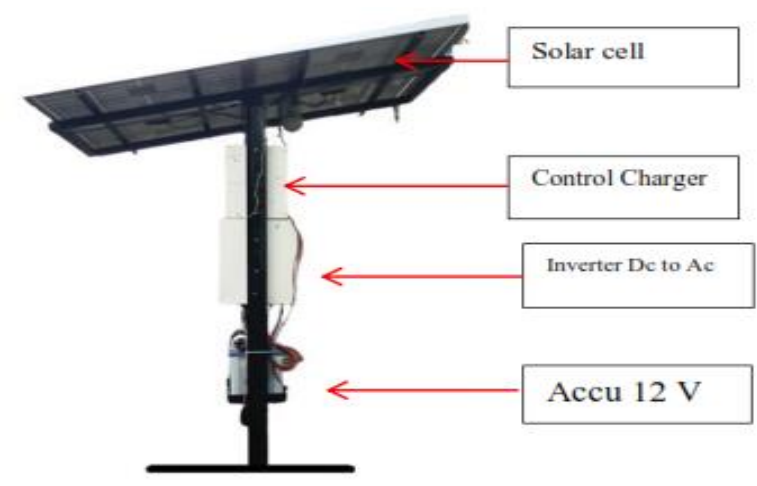

Gambar 2 Gambaran desain pembangkit listrik tenaga surya model portable.

Tabel 1 Spesifikasi kerangka alat

\begin{tabular}{lcl}
\hline \multicolumn{1}{c}{ Nama } & \multicolumn{1}{c}{ Ukuran } & \multicolumn{1}{c}{ Bahan } \\
\hline $\begin{array}{l}\text { Tiang kaki } \\
\text { rangka }\end{array}$ & $2 \times 150 \mathrm{~cm}$ & Besi canal U8 \\
$\begin{array}{l}\text { Penghubung kaki } \\
\text { rangka }\end{array}$ & $1 \times 80 \mathrm{~cm}$ & Besi canal U8 \\
$\begin{array}{l}\text { Tapakan kaki } \\
\text { rangka }\end{array}$ & $2 \times 80 \mathrm{~cm}$ & Besi U8 \\
$\begin{array}{l}\text { Sayap penyangga } \\
\text { utama }\end{array}$ & $150 \times 63 \mathrm{~cm}$ & $\begin{array}{l}\text { Baja ringan } \\
\text { Jari-jari }\end{array}$ \\
$\begin{array}{l}\text { Jari } \\
\text { penyangga panel }\end{array}$ & $4 \times 108 \mathrm{~cm}$ & $\begin{array}{l}\text { Baja ringan 2x2 } \\
\mathrm{cm}\end{array}$ \\
\hline
\end{tabular}

Tabel 2 Spesifikasi komponen alat

\begin{tabular}{|c|c|c|}
\hline Komponen & Sepesifikasi & Jumlah \\
\hline Solar cell & Polycritalin 50WP & 4 unit \\
\hline $\begin{array}{l}\text { SCC (solar } \\
\text { control } \\
\text { carger) }\end{array}$ & PWM 10A & 1 unit \\
\hline Inverter & $\begin{array}{l}\text { Pure sine wave } 2000 \\
\text { watt }\end{array}$ & 1 Unit \\
\hline Batrey & $\begin{array}{l}\text { Lead acid Dc } 12 v \\
70 A h\end{array}$ & 1 unit \\
\hline
\end{tabular}


Perancangan alat dimulai dengan merancang rangka penyangga pembangkit listrik yang terbuat dari bahan besi dengan melakukan pemotongan dan pengelasan sesuai dengan gambar perencanaan desain seperti yang dijelaskan pada Gambar 3 dan hasil dari perancangan rangka seperti pada Gambar 4

\section{- Kegiatan perakitan}

Kegiatan perakitan atau pemasangan alat di lokasi mitra dilaksanakan bersama anggota tim dengan didampingi oleh mitra, pemasangan alat di lokasi lahan kering atau tadah hujan yang terdapat sumur tanah atau sumur bor milik anggota kelompok tani Doro Manunggal, pada lahan ini terdapat sumur bor sedalam $60 \mathrm{~m}$ karena sesuai aturan pemerintah Kabupaten Ponorogo bahwa sumur untuk keperluan irigasi sawah harus mencapai sumber air dalam di bawah $60 \mathrm{~m}$ agar tidak mengganggu keberlansungan sumur untuk keperluan air minum masyarakat. Kedalaman permukaan air di Desa Duri umumnya berubah-ubah, saat musim hujan permukaan air sedalam $7 \mathrm{~m}$ dan pada saat musim kemarau permukaan air turun menjadi $20 \mathrm{~m}$, sehingga pada saat musim kemarau diperlukan pompa yang mampu memompa air dari kedalaman lebih dari $20 \mathrm{~m}$. Kegiatan pertama adalah memasang pompa air submersible ke

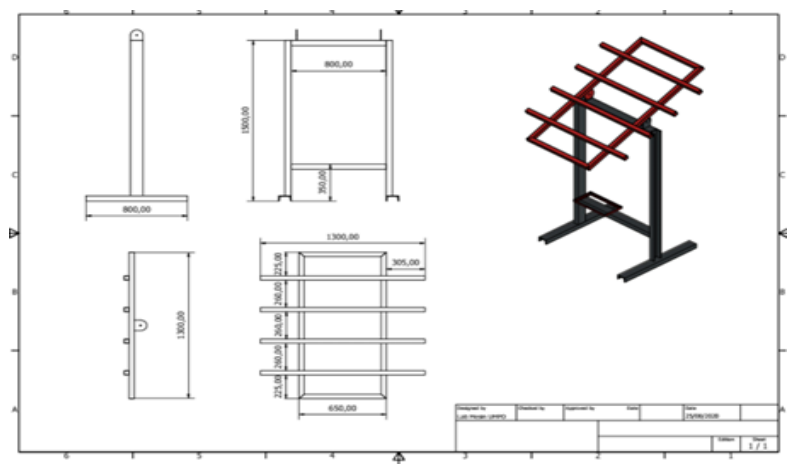

Gambar 3 Gambaran casis rencana alat.

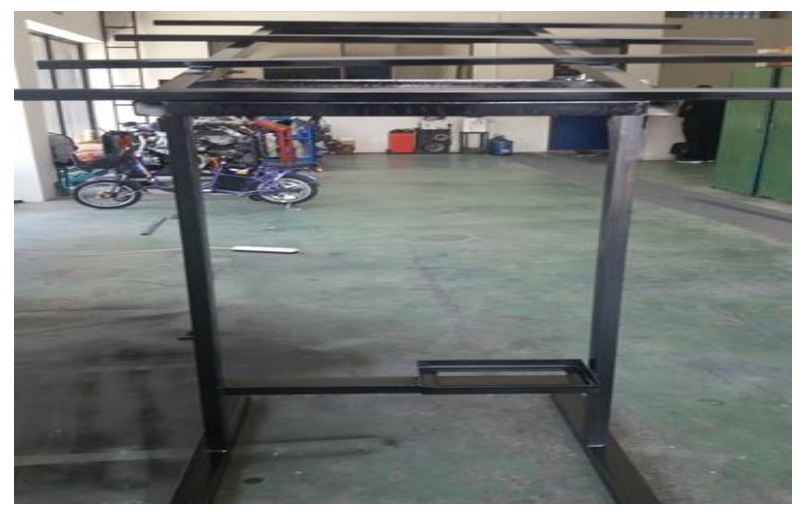

Gambar 4 Perancangan casis penyangga panel surya. dalam sumur bor seperti pada Gambar 5, selanjutnya melakukan perakitan sistem pembangkit listrik tenaga surya di area ladang yang sudah disiapkan oleh mitra seperti dijelaskan pada Gambar 6.

Sistem pembangkit listrik yang dipasang pada mitra terdiri dari komponen solar cell pengubah cahaya matahari menjadi listrik, solar control cargher berfungsi mengatur sistem pengisian pada batrey, accu berfungsi sebagai penyimpanan listrik yang dihasilkan oleh pembangkit, inverter komponen pengubah listrik DC tegangan 12 volt menjadi listrik AC tegangan 220 volt, saklar sebagai on-off penggunaan listrik pada pompa air (Bachtiar 2006).

\section{- Serah terima dan pelatihan penggunaan teknologi}

Serah terima alat dilaksanakan setelah keseluruan alat terpasang dan siap untuk digunakan. Serah terima alat diberikan kepada mitra untuk

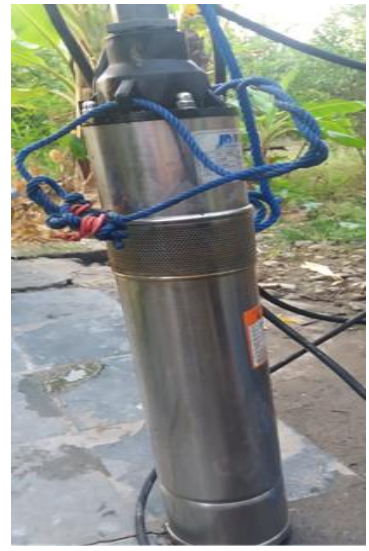

a

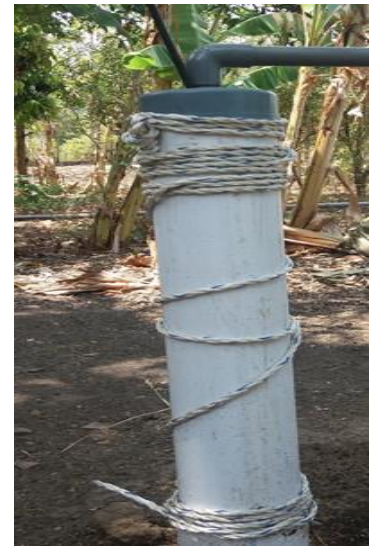

b
Gambar 5 a) Pompa air submersible yang akan di pasang pada sumur bor dan b)sumur bor yang telah terpasang pompa.

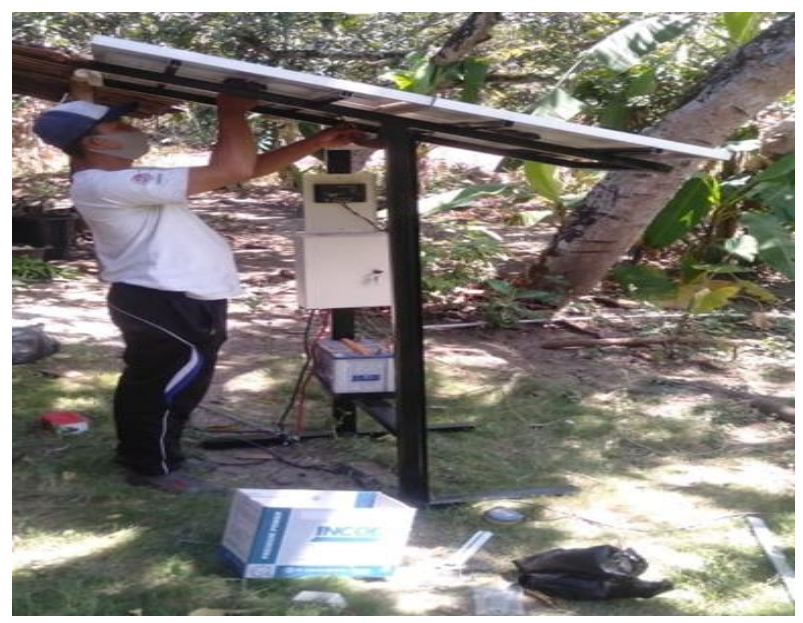

Gambar 6 Pemasangan sistem pembangkit listrik di lokasi mitra. 
digunakan dalam upaya memberikan solusi kepada permasalahan petani di Desa Duri dalam memenuhi kebutuhan irigasi pertanian. Serah terima alat berupa pompa air submersible bertenaga listrik tenaga surya dengan spesifikasi alat pompa air $0,5 \mathrm{hp}$ daya 370 watt output $3 / 4 \mathrm{dim}$, pembangkit listrik tenaga surya portable dengan daya $840 \mathrm{~W} / \mathrm{jam}$ output AC $220 \mathrm{~V}$, dan kemampuan panel surya menghasilkan energi listrik 200 WP.

Pelatihan penggunaan alat meliputi cara pemakaian pembangkit listrik dan perawatannya. Pembangkit listrik harus ditempatkan pada tempat yang terpapar sinar matahari sepanjang hari, saat posisi sinar matahari condong ke utara maka rangkaian panel surya dimiringkan ke arah utara menyesuaikan sudut datangnya matahari begitu sebaliknya saat matahari condong di arah selatan rangkaian panel surya dimiringkan ke arah selatan dengan mengatur setelen pada rangka penyangga panel surya. Penggunakan pompa harus memperhatikan kondisi batterey dalam kondisi $100 \%$ terisi selanjutnya tinggal menyalakan power yang terdapat pada modul pembangkit listrik, jika terdapat bunyi buzzer pada sistem inverter menandakan bahwa energi listrik mulai habis dan saatnya dihentikan pengunakan alat dan menunggu batterey penyimpanan solarcell terisi kembali kegiatan serah terima sekaligus pelatihan penggunaan alat seperti dijelaskan pada Gambar 7.

\section{Analisis Hasil Kegiatan}

Hasil dari kegiatan program pengabdian pada masyarakat ini bertujuan untuk mengatasi permasalahan sistem pengairan pada pertanain di Desa Duri dengan menerapkan pompa air menggunakan enelrgi listrik tenaga matahari yang digunakan untuk memompa sumber air tanah dari kedalaman lebih $20 \mathrm{~m}$. Teknologi pompa yang di terapkan menghasilkan debit air $1080 \mathrm{~L} / \mathrm{jam}$ dan bertahan selama 2 jam setiap siklus penuh pengisian battrey yakni 4 jam. Pompa dapat mengairi sawah seluas $100 \mathrm{~m}$ persegi dengan kedalam air resapan pada tanah kurang lebih $5 \mathrm{~cm}$ seperti pada Gambar 8. Hasil dari penerapan teknologi dapat digunakan untuk menanam sayur pada lahan yang dimiliki oleh mitra berupa tanaman sayur kangkung dan sawi, tanaman ini paling cocok ditanam saat musim kemarau dan cenderung mudah dalam perawatan serta nilai jualnya tinggi dan banyak dikonsumsi oleh masyarakat seperti yang dijalasakan pada Gambar 9.
Kendala yang dihadapi pada program ini salah satunya keamanan pada sistem pembangkit terhadaap gangguan pencuri karena merupakan barang baru dengan harga yang masih tinggi serta tempat penerapan di sawah maka diperlukan tindakan pengamanan terhadap alat yang di implementasikan. Selain itu, penggunaan alat dalam pengairan harus dilaksanakan dengan bertahap karena kemapuan batraey menyimpan listrik terbatas sehingga diperlukan system pembangkit yang lebih besar agar mampu melakukan pengairan pada tanaman sepanjang waktu. Upaya keberlanjutan program ini dengan peningkatam sistem pompa air dengan kemampuan lebih besar sehingga tidak hanya dapat digunakan untuk bertanam sayur saja tetapi

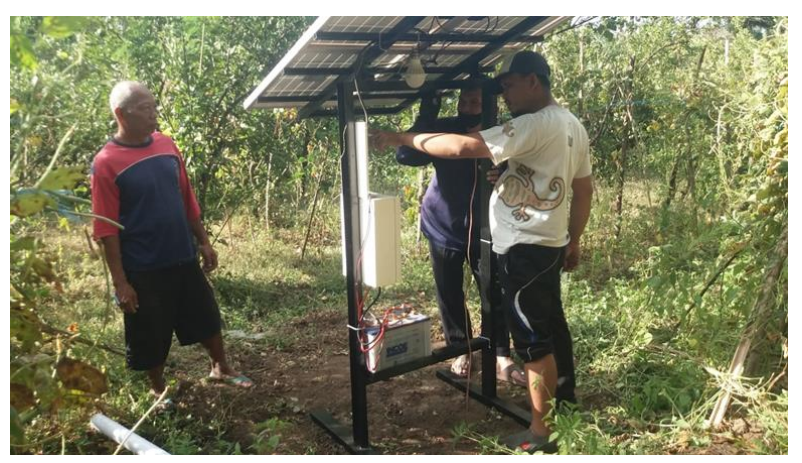

Gambar 7 Serah terima dan pelatihan penggunaan alat pada mitra.

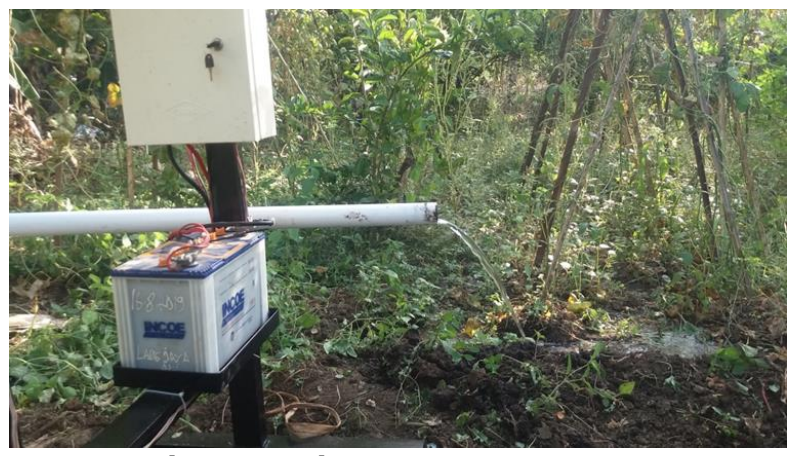

Gambar 8 Hasil Pengujian sistem irigasi.

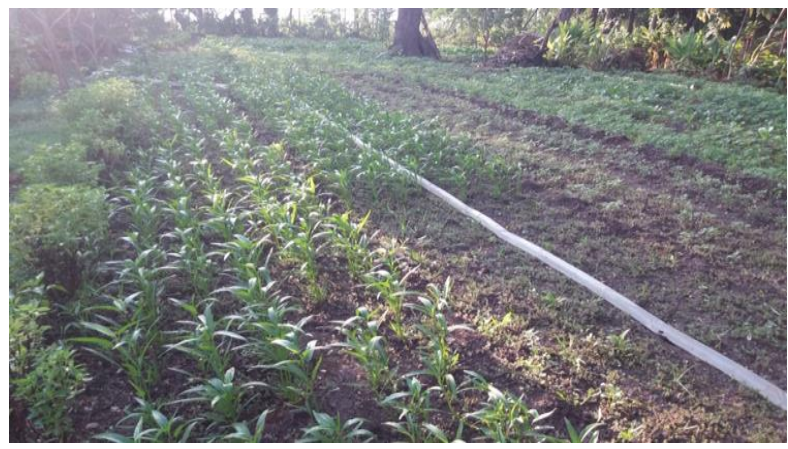

Gambar 9 Lahan tanaman sayur pada lahan kering tempat mitra. 
mampu digunakan untuk memenui kebutuhan pengairan tanaman palawija maupun padi yang membutuhkan air lebih banyak dibanding dengan tanaman sayur.

\section{SIMPULAN}

Kegiatan program pengabdian kepada masyarakat dengan tema pengembangan pompa irigasi pertanian menggunakan energi listrik tenaga surya di Desa Duri, Slahung, Ponorogo telah terlaksana dengan hasil telah terbangun satu unit sistem irigasi pertanian menggunakan air tanah dengan pompa air listrik dengan energi listrik terbarukan dan ramah lingkungan yakni pembangkit listrik tenaga surya berdaya 200 WP yang mampu memompa air dari kedalaman $20 \mathrm{~m}$ dan menghasilakn debit air 1080 L/jam. Pompa irigasi yang di bangun dapat digunakan untuk mengairi sawah tadah hujan di saat musim kemarau seluas $100 \mathrm{~m}^{2}$ setiap harinya serta dapat digunakan untuk bercocok tanaman sayur seperti sawi, kangkung, bayam, kenikir dan lainlain. Dengan adanyan sistem pomba irigasi energi listrik dari tenaga surya ini petani mampu menghemat pengeluaran biaya produksi pertanian kususnya biaya pengairan tanaman berupa pembelian bahan bakar minyak untuk pompa air mesin diesel sebesar 50\% serta petani mampu memproduksi sumber energi listrik secara mandiri. Sitem irigasi yang dibuat belum mampu digunakan untuk bercocok tanam jenis palawija maupun padi dengan sekala yang luas sehingga diperlukan sebuah teknologi yang sama dengan sekala lebih. Upaya penerapan teknologi serupa ditempat lain agar masyarakat khususnya petani mengerti tentang teknologi prtanian terbarukan yang lebih baik dan tidak menimbulkan polusi seperti pompa air menggunakan.

\section{DAFTAR PUSTAKA}

Arifin R, Malyadi M, Kurniawan E, Rosyidin ZU. 2020. Upaya Peningkatan Efektifitas
Pengairan Sawah dengan Sistem Kontrol Pompa Air Listrik. Dinamisia: Jurnal Pengabdian Kepada Masyarakat. 3(2): 228234. https://doi.org/10.31849/dinamisia. v3i2.3245

Bachtiar M. 2006. Prosedur Perancangan Sistem Pembangkit Listrik Tenaga Surya Untuk Perumahan (Solar Home System). Jurnal SMARTek. 4(3): 176-182.

[BAPPEDA] Badan Perencanaan Pembangunan Daerah Kabupaten Ponorogo. 2018. Profil Kecamatan Slahung. Ponorogo (ID): BPS Kabupaten Ponorogo Dalam Angka 2018.

Dewi VAK, Setiawan BI, Waspodo RSB. 2017. Analisis Konsumsi Air Sayuran Organik dalam Rumah Tanaman. Jurnal Irigasi. 12(1): 37-46. https://doi.org/10.31028/ji.v12.i1.37-46

Fitri HZ. 2017. Pengelompokan dan pemetaan wilayah kecamatan di kabupaten ponorogo berdasarkan potensi sektor pertanian menggunakan analisis klaster. [Thesis]. Surabaya (ID): Institut Teknologi Sepuluh Nopember.

Harini S. 2019. Kecamatan Slahung dalam angka. Ponorogo (ID): BPS Kabupaten Ponorogo 2019.

Kadir A. 2010. Energi Sumberdaya, Inovasi, Tenaga Listrik Dan Potensi EkonomiNo Title. Depok (ID): Universitas Indonesia.

Yasar M, Mustaqimah, Yunus Y. 2017. Potensi Pengembangan Sistem Irigasi Pompa Tenaga Surya untuk Sawah Tadah Hujan di Pulau Simeulue. Rona Teknik Pertanian Jurnal Ilmiah dan Penerapan Ketehnikan PertanianI. 10(2): 56-63. https://doi.org/10.17969/rtp.v10i2 .8757

Sanjaya OI, Giriantari IAD, Kumara INS. 2019. Perancangan Sistem Pompa Irigasi Pembangkit Listrik Tenaga Surya (PLTS) Untuk Pertanian Subak Semaagung. Jurnal SPEKTRUM, 6(3): 114-121. 